\title{
STUDIES ON INFLUENZA IN THE PANDEMIC OF 1957-1958. III. ISOLATION OF INFLUENZA A (ASIAN STRAIN) VIRUSES FROM INFLUENZA PATIENTS WITH PULMONARY COMPLICATIONS. DETAILS OF VIRUS ISOLATION AND CHARACTERIZATION OF ISOLATES, WITH QUANTITATIVE COMPARISON OF ISOLATION METHODS *
}

\author{
By EDWIN D. KILBOURNE
}

(From the Division of Virus Research, Department of Public Health and Preventive Medicine, New York Hospital-Cornell Medical Center, New York, N. Y.)

(Submitted for publication July 10, 1958; accepted August 7, 1958)

Because the preceding paper of this series (1) purports to document the entity of primary influenza virus pneumonia, the circumstances of the recovery of viruses from cases of influenza with pulmonary complications will be presented here in detail. In addition, the present paper will describe a preliminary study of certain properties of viral isolates from fatal and nonfatal cases, and corollary data on viral isolation methods.

\section{MATERIALS AND METHODS}

Collection of human materials for viral isolation. Throat washings with sterile $0.01 \mathrm{M}$ phosphate buffered saline were collected by gargling and frozen within one hour of collection in a $\mathrm{CO}_{2}$-ethanol mixture prior to storage at $-68^{\circ} \mathrm{C}$. Sections of viscera, urine and spinal fluid were similarly frozen and stored. Blood collected in acid-citrate-dextrose (ACD) was subjected to low speed centrifugation $(500 \mathrm{G})$ at $2^{\circ} \mathrm{C}$.; cellular and plasma fractions were frozen and stored separately. Prior to their inoculation, specimens were rapidly thawed in running cold tap water; streptomycin in a final concentration of $1.0 \mathrm{mg}$. per ml. and penicillin in a final concentration of 1,000 units per ml. were added. Throat washings were homogenized by refluxing them through a No. 20 needle. Lung specimens were weighed (except in the case of small needle aspirates) and homogenized as 5 or 10 per cent antibiotic-saline suspensions (by weight) at $4^{\circ} \mathrm{C}$. in either a Lourdes omnimixer or a Ten Broek grinder. Suspensions were centrifuged in plastic tubes at $8,200 \mathrm{G}$ for five minutes at room temperature. Supernatant fluid was used for inoculation and promptly refrozen.

Inoculation procedures. Ten to 11 day old chick embryos were used in all experiments unless it is otherwise indicated. Eighteen Gm. CFW male mice were employed in mouse lung studies. Monkey kidney cells for

* This investigation was supported in part by $\mathrm{Re}$ search Grants E-2162 and E-1595 from the National Institute for Allergy and Infectious Diseases, Public Health Service. tissue cultures were purchased from Microbiological Associates, Inc. in flasks. Tubes were seeded with 50,000 cells per tube. Cultures were grown for 48 hours before inoculation with a medium developed in this laboratory which contains 5 per cent calf serum and 0.5 per cent lactalbumin hydrolysate in Earle's balanced salt solution ( $\mathrm{pH}$ 7.0). Before inoculation, cells were washed three times with $2 \mathrm{ml}$. per tube of phosphate buffered 0.85 per cent saline; medium 199 was added as the maintenance medium. Incubation was effected at $35^{\circ} \mathrm{C}$. Three days after inoculation fluids were changed to forestall toxic effects of inocula (2), and tested for influenza virus hemagglutinin. After additional incubation for four days, fluids were again tested for hemagglutinin, pooled and subjected to additional passage for nine days. Tubes were observed daily for cytopathogenic effects.

Hemagglutinin titrations were performed by the addition of human $\mathrm{O}$ red blood cells (RBC) in initial concentration of 0.5 per cent to serially diluted viral suspensions. End points were determined after 60 minutes at $22^{\circ} \mathrm{C}$. by direct reading of tubes for hemagglutination patterns. Infectivity titrations of virus involved departures from usual methods and are described under "Results."

Electron microscopy was done by Dr. James Murphy of The Rockefeller Institute for Medical Research by a technique described earlier by Murphy and Bang (3).

\section{RESULTS}

\section{$A$ comparison of methods of viral isolation}

Early in the present study it became evident that influenza virus hemagglutinin was frequently noted in allantoic fluids from eggs inoculated by the amniotic route in primary passage isolation attempts. This observation, which suggested an unusual primary ability of the 1957 viruses to multiply in the allantoic sac without initial amniotic passage, prompted a quantitative comparison of the sensitivity of the amniotic and allantoic sacs to infection with small amounts of virus from human specimens. Although a frequently-quoted 
TABLE I

Simullaneous titrations by amniotic and allantoic routes of influenza virus of human lung suspension (Case G. H.)

\begin{tabular}{|c|c|c|c|}
\hline \multirow{2}{*}{$\begin{array}{c}\begin{array}{c}\text { Lung } \\
\text { suspension } \\
\text { dilution }\end{array} \\
\end{array}$} & \multicolumn{3}{|c|}{$\begin{array}{l}\text { Eggs positive for hemagglutinin } \\
\text { when injected by: }\end{array}$} \\
\hline & & $\underset{\text { route* }}{\text { Amniotic }}$ & $\underset{\text { route* }^{*}}{\text { Allantoic }}$ \\
\hline $\begin{array}{l}10^{-2} \\
10^{-3} \\
10^{-4} \\
10^{-5} \\
10^{-6}\end{array}$ & $\begin{array}{ll}+ & -1 \\
+ & - \\
0 & 0 \\
0 & 0 \\
0 & 0\end{array}$ & $\begin{array}{lllll}+ & + & D & D & D \\
+ & + & + & + & + \\
0 & 0 & 0 & 0 & + \\
0 & 0 & 0 & 0 & 0 \\
0 & 0 & 0 & + & D\end{array}$ & $\begin{array}{llll}+ & + & + & + \\
+ & + & + & + \\
0 & + & + & + \\
0 & 0 & 0 & 0 \\
0 & 0 & 0 & 0\end{array}$ \\
\hline $\begin{array}{l}\text { 1st passage } \\
\text { titer }\end{array}$ & & $10^{-2.7}$ & $10^{-3.5}$ \\
\hline $\begin{array}{l}\text { 2nd passage } \\
\text { (cumulative) } \\
\text { titer with } \\
\text { subinoculations }\end{array}$ & & $10^{-3.8}$ & $10^{-4.3}$ \\
\hline
\end{tabular}

* Bold face $t$ and 0 indicate results on 1st passage + indicates 1:4 dilution of amniotic or allantoic fluid positive for hemagglutinin; 0 indicates 1:4 dilution negative; $D$ indicates egg dead within 48 hours after injection, fluid not tested.

earlier paper (4) had indicated a much greater sensitivity of the amniotic route (in 13 day chick embryos) compared with the allantoic (in 11 day embryos), use of 13 day embryos has proved cumbersome in the hands of the present investigator. Amniotic fluid harvests are small in volume; fluids are opaque and high in urates and protein and often induce nonspecific hemagglutination in low dilution. The use of younger embryos of 9 to 11 days circumvents these difficulties and has proved successful in the past (5). Accordingly, comparison of amniotic and allantoic routes has been made in younger embryos of identical age and with the employment of identical incubation periods. In Table I are presented the results of simultaneous titration of a suspension of human lung by amniotic and allantoic injection of separate groups of 10 day old chick embryos. Amniotic inoculations were performed with a 1.5 inch No. 25 needle by the "blind" technique (6) under transillumination with a Prevue ${ }^{\circledR}$ egg candler; allantoic inoculation was effected by injection directly into the allantoic sac through a hole drilled in the side of the egg, also with a No. 25 needle. One-tenth $\mathrm{ml}$. volumes were injected by either route. Eggs were incubated at $35^{\circ} \mathrm{C}$. for 60 to 65 hours prior to harvest of individual fluids for hemagglutinin. The presence of hemagglutinin at the $10^{-6}$ dilution in one egg inoculated amniotically suggested the possibility that virus below the concentration required for hemagglutination might be present in the "skipped" dilutions which were negative for hemagglutinin. Each negative fluid (not in bold face in the table) was injected undiluted by the allantoic route into two eggs which were incubated for a further 40 hours. This subinoculation did in fact reveal latently positive eggs in the initial titration but did not contribute appreciably either to elevation of apparent viral titers or to the relative concentrations of virus revealed by the two routes of inoculation. By either endpoint the allantoic method appeared certainly no less sensitive than the amniotic to high dilutions of virus.

The possibility was considered that this result might be characteristic only of virus recovered directly from human tissue or from fatal cases of influenza. However, titration under similar conditions of virus in the throat washing of a nonfatal case (Table II) again attested to the comparable sensitivity of allantoic and amniotic routes of inoculation.

\section{Further isolations by the allantoic route-The in-} fuence of cortisone

In view of the possibility that these viruses from only two cases may have been atypical in behavior, four additional throat washings which had previously yielded virus upon amniotic inoculation were injected (undiluted) by the allantoic route into groups of six 10 day old eggs which were subsequently incubated for 60 hours. Results of first and second passages by this method are presented in Table III. Undiluted allantoic pools were em-

TABLE II

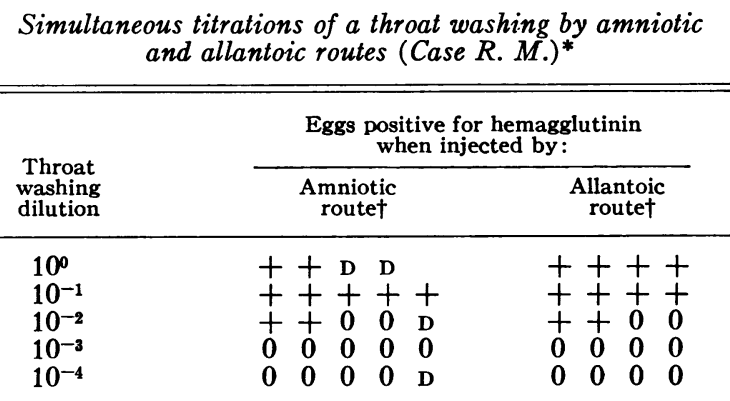

* Nonfatal case of influenza.

$\dagger+, 1: 4$ dilution of amniotic or allantoic fluid positive for hemagglutinin; $0,1: 4$ dilution negative; $D$, egg dead within 48 hours after injection, fluid not tested. 
TABLE III

Recovery of influenza viruses by allantoic inoculation from throat washings previously positive by amniotic inoculation

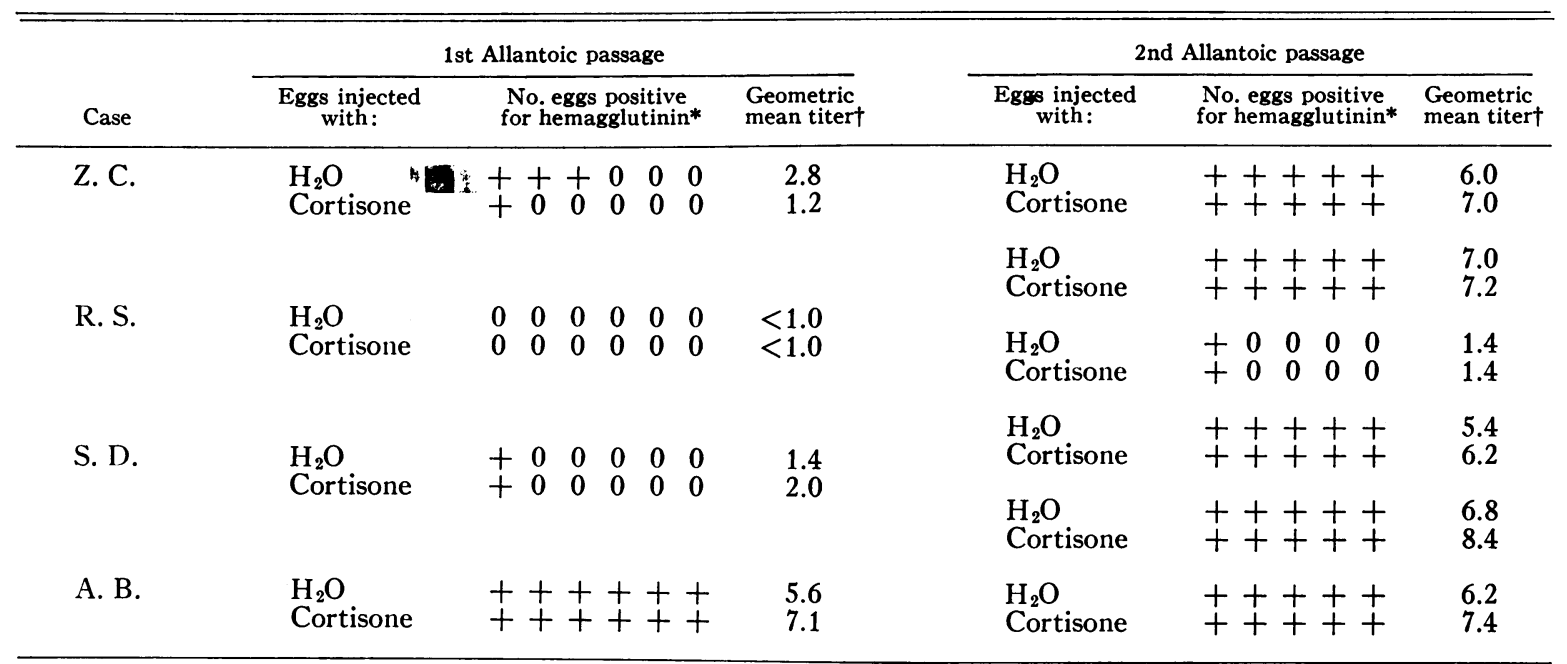

* At $1: 4$ dilution of allantoic fluid.

$\dagger \log _{2}$ viral hemagglutinin (e.g., $6.0=$ conventional titer of 1:64).

ployed for second passage inocula. Either hydrocortisone diethylaminoacetate hydrochloride ("cortisone"), $0.001 \mathrm{mg}$., or distilled $\mathrm{H}_{2} \mathrm{O}$ was injected two hours prior to virus-containing materials. It was expected that cortisone, by inhibiting the possible interfering effects of inactive or nonreplicating virus of the inocula (7), might expedite demonstration of virus by enhancing final virus yields. It may be noted in Table III that cortisone was essentially of no practical value in effecting viral isolations although a trend toward higher concentrations of hemagglutinating virus was usually observed with the steroid.

In comparison with previous amniotic isolations, three of the four washings yielded hemagglutinin on initial allantoic passage. The sole exception, the throat washing of Case R.S., yielded a peculiarly slow-growing virus which is still under investigation. Repetition of the second allantoic passage with this virus with $10^{\circ}$ and $10^{-2}$ dilutions of inocula resulted in detectable hemagglutinin only with the undiluted inoculum even after 72 hours of incubation. The data summarized in Table III support the evidence presented earlier concerning the effectiveness of the allantoic method of inoculation.

\section{Other methods of viral isolation}

The reported use of monkey kidney tissue culture for influenza virus isolation $(8,9)$ prompted a comparison of this method of viral propagation with chick embryo techniques. In addition, the possibility that isolates from human lung might multiply best in pulmonary tissue suggested a trial of mouse inoculation despite the reported insensitivity of this host in primary isolation attempts (10). Groups of mouse lungs (removed three days after intranasal inoculation of mice with varying dilutions) were ground as 5 per cent suspensions in saline with antibiotics in a blender, then subjected to centrifugation at room temperature of $8,200 \mathrm{G}$ for five minutes. Supernatant fluids were subinoculated by the allantoic route into 10 day old eggs which were then incubated for 65 hours; allantoic fluids were tested at $1: 4$ dilution for viral hemagglutinin. The result of a titration by this method of virus in a human lung may be seen in Table IV. It will be noted that combined mouse-egg passage (11) yielded virus only at the initial dilution of $10^{-1}$ while single passage allantoic inoculation of 10 day old eggs detected

TABLE IV

Simultaneous titrations by chick embryo (allantoic), mousechick embryo, and tissue culture methods of infuenza virus in human lung (Case C. P.)

\begin{tabular}{lccc}
\hline & $\begin{array}{c}\text { Chick } \\
\text { embryo } \\
\text { (allantoic) }\end{array}$ & $\begin{array}{c}\text { Mouse- } \\
\text { chick } \\
\text { embryo }\end{array}$ & $\begin{array}{c}\text { Monkey } \\
\text { kidney } \\
\text { tissue } \\
\text { culture }\end{array}$ \\
\hline Titer ID ID $_{50}$ & $10^{-4.7}$ & $10^{-1}$ & $<10^{-1}$ \\
\hline
\end{tabular}


TABLE V

Attempted isolation of influenza virus by mouse inoculation* of throat washings previously tested in eggs

\begin{tabular}{|c|c|c|c|c|c|}
\hline \multirow[b]{3}{*}{ Case } & \multicolumn{3}{|c|}{$\begin{array}{l}\text { Throat washing tested } \\
\text { in eggs was: }\end{array}$} & \multirow{2}{*}{\multicolumn{2}{|c|}{$\begin{array}{l}\text { Result of isolation } \\
\text { attempt in mice: }\end{array}$}} \\
\hline & \multirow[b]{2}{*}{$\begin{array}{c}\text { Posi- } \\
\text { tive }\end{array}$} & \multirow{2}{*}{$\begin{array}{c}\text { Estimated } \\
\text { viral } \\
\text { concen- } \\
\text { tration } \dagger\end{array}$} & \multirow[b]{2}{*}{$\begin{array}{l}\text { Nega- } \\
\text { tive }\end{array}$} & & \\
\hline & & & & $\begin{array}{l}\text { Posi- } \\
\text { tive }\end{array}$ & $\begin{array}{l}\text { Nega- } \\
\text { tive }\end{array}$ \\
\hline Z. C. & + & + & & & + \\
\hline R. S. & + & + & & & + \\
\hline S. D. & + & + & & & + \\
\hline A. B. & + & $++t$ & & + & \\
\hline M. E. & & & + & & + \\
\hline A. M. & & & + & & + \\
\hline D. P. & & & + & & + \\
\hline B. N. & & & + & & + \\
\hline M. M. & & & + & & + \\
\hline
\end{tabular}

* Groups of five mice were inoculated intranasally with the throat washing; lungs were harvested two days later, pooled and homogenized as 5 per cent suspensions by

weight. Groups of five eggs were inoculated with the 5 per cent lung homogenates; allantoic fluids harvested 60 hours later were tested for hemagglutinin.

$\dagger+$ indicates no allantoic fluids positive for viral hemagglutination on first passage. +++ indicates one-half of allantoic fluids positive for viral hemagglutination on first passage or actual titration of EID $_{50}$ per $1.0 \mathrm{Gm}$. of lung (wet weight) by chick embryo allantoic route.

virus at a dilution of more than $10^{-4}$. No dilution inoculated into monkey kidney tissue cultures induced demonstrable cytopathogenic' effects or hemagglutinin formation despite subinoculation as outlined in "Materials and Methods." Inoculation of monkey kidney tissue cultures with the four throat washings positive by both amniotic and allantoic injection (Table III) similarly failed to demonstrate virus.

A similar test of the efficiency of the mouse-egg method resulted in the recovery of virus from only one of four throat washings previously shown to contain virus by primary egg inoculation (Table V). This sole positive specimen had had the highest estimated virus concentration when inoculated into eggs. No throat washings negative in eggs were positive with any other method.

\section{Recovery of virus from patients with pulmonary complications}

By the use of the amniotic or allantoic inoculation techniques which have been described, hemagglutinating viruses were recovered from specimens of lungs or throat washings of 14 influenza patients in whom acute pulmonary signs were apparent. A record of these viral isolations is listed in Table VI.
In two patients (G.S. and C. B.) only transient signs of pulmonary infection were evident and bacterial infection was not demonstrated (1). As discussed in the preceding paper of this series (1), six patients showed no evidence of bacterial pneumonia despite signs of extensive pulmonary consolidation. From five of these patients who died (Cases G.H., C.P., A.B., J.B. and A.C.) virus was recovered with ease from either lung suspensions or throat washings. Further, virus was usually present in high concentration as estimated by the frequency of hemagglutinin-positive allantoic fluids following initial amniotic inoculation (see footnote to Table VI). (Amniotic fluids were often pooled during the harvest so that individual hemagglutinin determinations on these fluids were not always feasible.)

The ease with which virus was demonstrated in the lungs of fatal cases was related directly to its subsequently determined concentration (Cases G.H., C.P., A.B., F.R., A.Z.), and was (with the exception of Case A.C.) inversely related to the estimated duration of illness prior to death. In the case of Patients F.R. and A.Z., in whom pulmonary virus was demonstrated with difficulty, lung sections were excised at autopsy nine to 10 days after the onset of illness. In light of the fact that circulating antibody may be demonstrated as early as the seventh day of influenza (12), it is understandable that virus was not demonstrable in high concentration in these cases. Indeed, influenza virus is detected with difficulty in the lung of the mouse nine days after initiation of infection (13). Virus was reisolated (in the course of titrations) from the four of the six fatal cases in which pulmonary virus was previously demonstrated in concentrations greater than $10^{2} \mathrm{EID}_{50}$ per Gm. of lung. In Case A.B. a small needle aspirate was obtained just ante mortem. This lung fragment was not weighed, so that the titration figure of $10^{4}$ (Table VI) is probably below the actual concentration of virus, as the tissue was diluted an undetermined amount in homogenization of the specimen. In all instances when death occurred before the tenth day of illness virus was recovered from the lung.

\section{Cases of influenza with pulmonary complications from which virus was not isolated}

From 15 patients with clinical influenza and evidence of pulmonary disease, influenza viruses 
EDWIN D. KILBOURNE

TABLE VI

Recovery of influenza viruses from patients with pulmonary complications

\begin{tabular}{|c|c|c|c|c|c|c|}
\hline Case & $\begin{array}{l}\text { Bacterial } \\
\text { complications }\end{array}$ & $\begin{array}{c}\text { Specimen } \\
\text { source* }\end{array}$ & $\begin{array}{l}\text { Day } \\
\text { specimen } \\
\text { obtained } \dagger\end{array}$ & $\begin{array}{c}\text { Virus } \\
\text { recovered }\end{array}$ & $\begin{array}{l}\text { Estimated } \\
\text { virus } \\
\text { concentration } \ddagger\end{array}$ & $\begin{array}{c}\text { Virus } \\
\text { reisolated }\end{array}$ \\
\hline $\begin{array}{l}\text { G. S. } \$ \\
\text { C. B. } \$\end{array}$ & $\begin{array}{l}\text { None } \\
\text { None }\end{array}$ & $\begin{array}{l}\text { T.W. } \\
\text { T.W. } \\
\text { RBC }\end{array}$ & $\begin{array}{l}2 \\
5 \\
5\end{array}$ & $\stackrel{+}{+}$ & $\begin{array}{l}++ \\
++\end{array}$ & $\begin{array}{l}\text { N.D.** } \\
\text { N.D. }\end{array}$ \\
\hline $\begin{array}{l}\text { G. H. } \\
\text { C. P. } \\
\text { A. B. }\end{array}$ & $\begin{array}{l}\text { None } \\
\text { None } \\
\text { None }\end{array}$ & $\begin{array}{l}\text { Lung } \\
\text { Lung } \\
\text { Lung| } \\
\text { T.W. } \\
\text { Urine }\end{array}$ & $\begin{array}{l}5 \\
5 \\
5 \\
4 \\
3 \\
3\end{array}$ & $\begin{array}{l}+ \\
+ \\
+ \\
+ \\
0\end{array}$ & $\begin{array}{l}+++\left(10^{5.3}\right) \\
+++\left(10^{5.7}\right) \\
+++\left(10^{4}\right) \\
+++\end{array}$ & $\begin{array}{l}2 \mathrm{x} \\
2 \mathrm{x} \\
1 \mathrm{x} \\
2 \mathrm{x}\end{array}$ \\
\hline J. B. & None & $\begin{array}{l}\text { T.W. } \\
\text { Lung } \\
\text { CSF } \\
\text { Urine }\end{array}$ & $\begin{array}{r}5 \\
3 \\
10 \\
5 \\
3\end{array}$ & $\begin{array}{l}+ \\
+ \\
0 \\
0 \\
0\end{array}$ & +++ & N.D. \\
\hline A. C. & None & $\begin{array}{l}\text { T.W. } \\
\text { Lung }\end{array}$ & $\begin{array}{l}3 \\
4\end{array}$ & + & $\begin{array}{l}+++ \\
+\left(<10^{2}\right)\end{array}$ & N.D. \\
\hline P. E. & Pneumococcal & $\begin{array}{l}\text { T.W. } \\
\text { CSF }\end{array}$ & $\begin{array}{l}3 \\
6\end{array}$ & $\begin{array}{l}+ \\
0\end{array}$ & + & N.D. \\
\hline $\begin{array}{l}\text { E. R. } \\
\text { M. L. }\end{array}$ & $\begin{array}{l}\text { Pneumococcal } \\
\text { Pneumococcal }\end{array}$ & $\begin{array}{l}\text { T.W. } \\
\text { T.W. } \\
\text { RBC }\end{array}$ & $\begin{array}{l}1 \\
3 \\
3\end{array}$ & $\begin{array}{l}+ \\
+ \\
0\end{array}$ & $\stackrel{+}{+}+$ & $\begin{array}{l}\text { N.D. } \\
\text { N.D. }\end{array}$ \\
\hline F. R. & Pneumococcal & $\begin{array}{l}\text { T.W. } \\
\text { Lung } \\
\text { RBC }\end{array}$ & 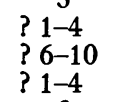 & $\begin{array}{l}+ \\
+ \\
0\end{array}$ & $\begin{array}{l}+++ \\
+\left(<10^{2}\right)\end{array}$ & $\begin{array}{l}\text { N.D. } \\
0\end{array}$ \\
\hline $\begin{array}{l}\text { G. A. } \\
\text { A. } Z \text {. }\end{array}$ & $\begin{array}{l}\text { Staphylococcal } \\
\text { Staphylococcal }\end{array}$ & $\begin{array}{l}\text { T.W. } \\
\text { T.W. } \\
\text { Lung } \\
\text { Urine } \\
\text { RBC }\end{array}$ & $\begin{array}{r}3 \\
4 \\
10 \\
4 \\
4\end{array}$ & $\begin{array}{l}+ \\
+ \\
+ \\
0 \\
0\end{array}$ & $\begin{array}{l}++ \\
\quad+\left(10^{2}\right)\end{array}$ & $\begin{array}{l}\text { N.D. } \\
\text { N.D. } \\
0\end{array}$ \\
\hline B. P. & Staphylococcal & $\begin{array}{l}\text { Sputum } \\
\text { Lung }\end{array}$ & $\begin{array}{l}5 \\
5\end{array}$ & $\begin{array}{l}0 \\
+\end{array}$ & $+++\left(10^{2.7}\right)$ & $1 x$ \\
\hline
\end{tabular}

* T.W., throat washing; RBC, red blood cells; CSF, cerebrospinal fluid.

$\dagger$ Day of illness.

$\ddagger$ indicates no allantoic fluids positive for viral hemagglutinin on 1 st passage. ++ indicates $<$ one-half of allantoic fluids positive for viral hemagglutinin on 1st passage. +++ indicates one-half of allantoic fluids positive for viral hemagglutinin on 1st passage or actual titration of $\mathrm{EID}_{50}$ per $1.0 \mathrm{Gm}$. of lung (wet weight) by chick embryo allantoic route.

$\S$ Transient pulmonary signs noted.

|| Lung puncture.

** N.D., reisolation not attempted.

were not isolated despite serological substantiation of infection in all cases (1). However, consideration of Table VII shows that in only four of these cases (27 per cent) were throat washings obtained earlier than the fifth day of illness. It is uncommon to recover virus after this time (14). In most of these patients a secondary bacterial complication had ensued-further evidence that viral isolation was essayed relatively late in the course of the primary influenza virus infection (1).

\section{Failure to demonstrate virus in nonrespiratory sources}

Demonstration that a viremia may occur in mice infected with influenza virus (15) led to reinvestigation of the possibility of viremia in human dis- ease. To this purpose specimens of erythrocytes and urine were studied which were obtained early in illness from patients in whom respiratory tract virus had been demonstrated. Despite concentration of urine 3- to 10-fold and the expectation that blood stream virus might have been adsorbed in vivo to $\mathrm{RBC}$ suspensions, attempts at virus recovery were fruitless. Spinal fluids from patients who exhibited neurological symptoms were also negative for virus.

\section{Identification of viral isolates}

All isolates from either lungs or throat washings were serologically identified as Asian strain influenza $A$ viruses by hemagglutination-inhibition tests. Complex antigenic analysis of isolates by 
TABLE VII

Serologically proved cases of influenza with pulmonary complications from which virus was not recovered

\begin{tabular}{|c|c|c|c|}
\hline Case & Bacterial complications & $\begin{array}{l}\text { Specimen } \\
\text { source }\end{array}$ & $\begin{array}{l}\text { Day of } \\
\text { illness } \\
\text { on which } \\
\text { specimen } \\
\text { was } \\
\text { obtained }\end{array}$ \\
\hline G. V.* & None & T.W.† & 2 \\
\hline D. P. & Pneumococcal & T.W. & 7 \\
\hline H.G. & Staphylococcal & $\begin{array}{l}\text { T.W. } \\
\text { Urine }\end{array}$ & $\begin{array}{l}7 \\
8\end{array}$ \\
\hline P. B. & None & T.W. & 2 \\
\hline B. N. & Aerobacter & T.W. & 15 \\
\hline M. M. & Pneumococcal & T.W. & 6 \\
\hline P. R. & Pneumococcal & $\begin{array}{l}\text { T.W. } \\
\text { Urine }\end{array}$ & $\begin{array}{l}4 \\
5\end{array}$ \\
\hline C. G. & H. influenzae and staph. & T.W. & 12 \\
\hline R. L. & Pneumococcal & T.W. & 7 \\
\hline N. M. & Pneumococcal & T.W. & 6 \\
\hline R. C. & Staphylococcal & $\begin{array}{l}\text { T.W. } \\
\text { Lung }\end{array}$ & $\begin{array}{r}5 \\
53\end{array}$ \\
\hline A. L. & Pneumococcal & T.W. & 1 \\
\hline H. W. & Staphylococcal & T.W. & 35 \\
\hline L. F. & Staphylococcal & T.W. & 9 \\
\hline A. M. & Pneumococcal & T.W. & 7 \\
\hline
\end{tabular}

${ }^{*}$ Rales on auscultation; no roentgenographic evidence of infiltrate.

$\dagger$ T.W., throat washing.

the production of isolate-specific antisera was not done. However, all isolates were inhibited to at least the same degree as the homologous virus by antiserum for the Japan 305 strain of influenza A virus.

A comparison of viral isolates from lungs and throat washings of fatal and nonfatal cases

It has been stressed in the foregoing paper (1) that fatal influenza occurred usually in a setting of abnormal host physiology. There is, therefore, no need to postulate an increased virulence of the virus infecting and recovered from such cases. There is, in fact, no biological characteristic of influenza viruses which has been correlated with their virulence for man, and thus no way of demonstrating that one viral isolate differs in virulence from another. The problem is complicated further by the probable heterogeneity of viral particles in any given isolate, and the inevitable shifting of the proportion of each type of particle with laboratory cultivation of the virus. It is therefore difficult to relate the sum of the properties of even early passage egg-adapted virus to the pristine character of this virus as it induced infection in man. Nevertheless, crude correlations may be drawn in that it can be stated that the somewhat greater capacity of influenza A viruses to induce more severe illness in man than is caused by influenza $B$ viruses parallels the relatively greater capacity of influenza A viruses to damage the lung of the mouse in early passages.

Although an earlier experiment (Table V) had failed to show that viruses in human lung suspensions (from fatal cases) were unduly capable of initiating murine infection, it was considered of interest to compare the relative pulmonary toxicity of the larger amounts of such viruses provided by cultivation in eggs. As outlined in Table VIII, equivalent masses of virus derived from either the throat washings of nonfatal cases or the lungs of fatal cases were inoculated intranasally into groups of 10 mice each. Viruses were at the stage of either second or third egg passage. Mice were killed after five days and gross pulmonary lesions were scored (16). Only with virus from a nonfatal case were significant lesions produced.

TABLE VIII

Mouse lung toxicity of influenza viruses isolated in eggs from fatal and nonfatal cases of influenza

\begin{tabular}{|c|c|c|c|c|c|c|c|}
\hline \multirow[b]{2}{*}{ Case } & \multirow[b]{2}{*}{ Fatal } & \multirow[b]{2}{*}{$\begin{array}{l}\text { Source of } \\
\text { isolate }\end{array}$} & & & \multicolumn{2}{|c|}{ Viral inoculum } & \multirow{2}{*}{$\begin{array}{l}\text { Total } \\
\text { lesion } \\
\text { score } \\
\text { (10 mice) }\end{array}$} \\
\hline & & & \multicolumn{2}{|c|}{$\begin{array}{l}\text { Egg passage } \\
\text { of isolate* }\end{array}$} & $\begin{array}{l}\text { Original } \\
\text { HA titer }\end{array}$ & Dilution & \\
\hline R. S. & & T.W. & $\mathrm{Am}_{1}$ & $\mathrm{All}_{1}$ & 2,048 & $1: 16$ & 0 \\
\hline R. M. & & T.W. & $\mathrm{All}_{2}$ & & 128 & 0 & 0 \\
\hline S. D.t & & T.W. & $\mathrm{Am}_{1}$ & $\mathrm{All}_{1}$ & 512 & $1: 4$ & 24 \\
\hline C. $\mathrm{P}$. & Died & Lung & $\mathrm{All}_{2}$ & & 128 & 0 & 1 \\
\hline A. B. & Died & Lung & $\mathrm{All}_{2}$ & & 256 & $1: 2$ & 3 \\
\hline A. $Z$. & Died & Lung & $\mathrm{Am}_{1}$ & $\mathrm{All}_{2}$ & 128 & 0 & 0 \\
\hline
\end{tabular}

* Am, amniotic route; All, allantoic route.

$\dagger$ Reciprocal of the maximal dilution of the preparation which induces hemagglutination.

$\ddagger$ Original throat washing negative in mice (Table V). 


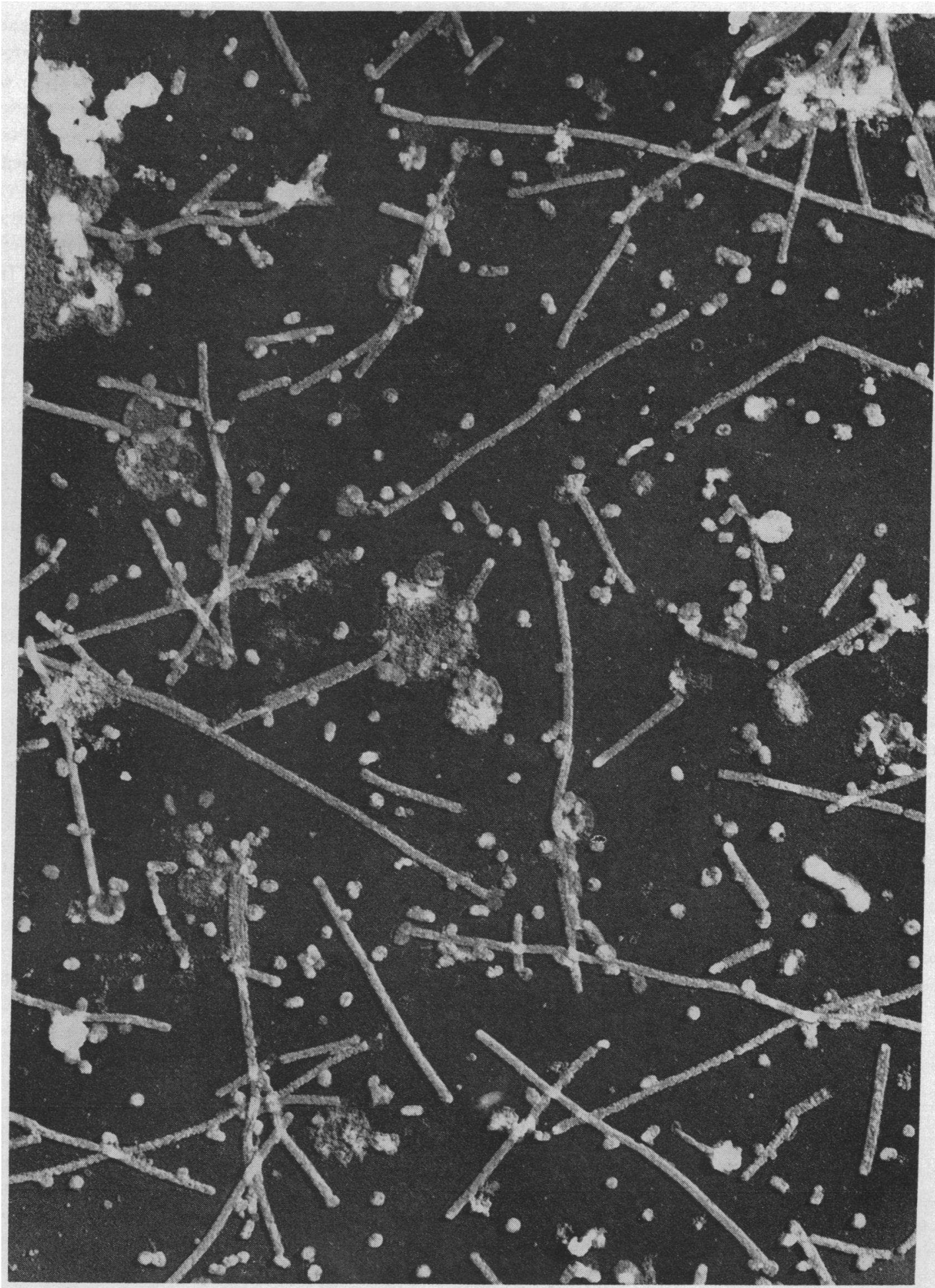

Fig. 1. Electron Microscopy $(\times 19,600)$ of Influenza Virus Isolate from the Throat Washing of a Nonfatal Case (Case R.M.)

Chromium shadow- $\mathrm{OsO}_{4}$ fixation. Both filamentous and spheroidal forms of the virus are illustrated. This picture is representative of all isolates which were examined from fatal and nonfatal cases. Electron microscopy by Dr. James S. Murphy. 
Therefore, further investigations along this line did not appear promising.

The morphology of a number of isolates was examined by electron microscopy. In three experiments performed in collaboration with Dr. James Murphy of The Rockefeller Institute for Medical Research, isolates from three nonfatal cases without pulmonary involvement and from lung and throat washings of six fatal cases were examined by electron microscopy. Viral preparations were made by a technique which has been previously reported (3). Although detailed examination (with actual measurements of particles) was not undertaken, it was apparent that marked differences among isolates were not readily discernible. In most preparations filaments predominated. A preparation representative of the morphology of both "fatal" and "nonfatal" isolates is illustrated in Figure 1. Spherical and filamentous forms of the virus may be observed in this photograph.

Hemagglutinating characteristics of viruses from fatal and nonfatal cases were studied. In summary, all isolates agglutinated human, sheep and chicken erythrocytes. The relative titers of viral hemagglutination with the various cells did not differ significantly regardless of the origin of the viral isolate.

\section{DISCUSSION}

Influenza $\mathrm{A}$ virus has been isolated and reisolated from the lungs of influenza patients with nonbacterial pulmonary involvement. In patients who died early in illness the concentration of pulmonary virus was usually high-comparable to the concentrations observed in the experimental disease of mice at a comparable stage of infection. Lower concentrations of virus have been demonstrated in two patients in whom bacterial complications precipitated hospitalization and who were (on the basis of historical evidence) at a later stage of influenza.

An unexpected corollary of the present study has been a demonstration of the equal efficacy of the allantoic and amniotic routes of chick embryo inoculation for recovery of influenza $A$ virus of the Asian strain.

An expected corollary of the study has been the failure to demonstrate differences in viral isolates from fatal and nonfatal cases.

\section{SUMMARY}

1. Influenza A virus (Asian strain) was isolated from 14 patients with influenza who exhibited pulmonary complications. From four fatal cases it was recovered directly from lung tissue to the exclusion of any other pathogen. From three fatal cases virus was recovered from the lung coincident with the recovery of pneumococci or staphylococci.

2. With the viruses studied, the chick embryo proved the most susceptible host and the allantoic route of inoculation of this host equaled the amniotic in sensitivity.

3. Limited studies failed to demonstrate differences in toxicity, hemagglutination capacity or morphology of isolates from fatal and nonfatal cases.

\section{REFERENCES}

1. Louria, D. B., Blumenfeld, H. L., Ellis, J. T., Kilbourne, E. D., and Rogers, D. E. Studies on influenza in the pandemic of 1957-1958. II. Pulmonary complications of influenza. J. clin. Invest. 1959, 38, 213.

2. Mogabgab, W. Personal communication.

3. Murphy, J. S., and Bang, F. B. Observations with the electron microscope on cells of the chick chorioallantoic membrane infected with influenza virus. J. exp. Med. 1952, 95, 259.

4. Hirst, G. K. Direct isolation of influenza virus in chick embryos. Proc. Soc. exp. Biol. (N. Y.) 1945, 58, 155.

5. Kilbourne, E. D., Anderson, H. C., and Horsfall, F. L., Jr. Concurrent infection with influenza $A$ and $B$ viruses in a single epidemic of influenza. J. Immunol. 1951, 67, 547.

6. Hirst, G. K. Direct isolation of human influenza virus in chick embryos. J. Immunol. 1942, 45, 293.

7. Kilbourne, E. D. The influence of cortisone on experimental viral infection. IV. Negation of interference as the mechanism by which cortisone induces increased virus yields. J. exp. Med. 1957, $106,863$.

8. Takemoto, K. K., Lynt, R. K., Rowe, W. P., Huebner, R. J., Bell, J. A., Mellin, G. W., and Davis, D. J. Primary isolation of influenza $A, B$ and $C$ viruses in monkey kidney tissue cultures. Proc. Soc. exp. Biol. (N. Y.) 1955, 89, 308.

9. Vogel, J., and Shelokov, A. Adsorption-hemagglutination test for influenza virus in monkey kidney tissue culture. Science 1957, 126, 358. 
10. Francis, T., Jr., and Magill, T. P. Direct transmission of human influenza virus to mice. Proc. Soc. exp. Biol. (N. Y.) 1937, 36, 132.

11. Kilbourne, E. D., and Horsfall, F. L., Jr. Mouse-egg neutralization. Neutralization in the mouse of influenza viruses not adapted to the mouse. J. Immunol. 1951, 67, 431.

12. Horsfall, F. L., Jr., Hahn, R. G., and Rickard, E. R. Four recent influenza epidemics: An experimental study. J. clin. Invest. 1940, 19, 379.

13. Kilbourne, E. D. Unpublished data.
14. Hirst, G. K. Laboratory diagnostic procedures for influenza in Diagnosis of Viral and Rickettsial Infections, F. L. Horsfall, Jr., Ed. New York, Columbia University Press, 1949, p. 5.

15. Hamre, D., Appel, J., and Loosli, C. G. Viremia in mice with pulmonary influenza $A$ virus infections. J. Lab. clin. Med. 1956, 47, 182.

16. Horsfall, F. L., Jr. Neutralization of epidemic influenza virus. The linear relationship between the quantity of serum and the quantity of virus neutralized. J. exp. Med. 1939, 70, 209. 